\title{
Effect of Feeding Cake Fortified with Different Concentrations of Ashwagandha Root against Sodium Arsenite Toxicity in Male Rats
}

\author{
Samah A. Elsemelawy ${ }^{1}$ and Rehab Ibrahim Tag Al Deen ${ }^{2}$ \\ ${ }^{1}$ Home Economics Dept., Faculty of Specific Education, Tanta University .Egypt. \\ ${ }^{2}$ Home Economics Dept., Faculty of Specific Education, Zagazig University, Egypt.
}

\section{ABSTRACT}

T $n$ ayurvedic medicine, herbal plants as ashwagandha (Withania somnifera) were used as a powerful plant to cure many of diseases. The present study was carried out to evaluate the protective effect offortified cake by different concentrations of ashwagandha root powder against sodium arsenite induced toxicity in rats. Thirty male Sprague-Dawley rats weighing $(120 \pm 10 \mathrm{~g})$. Rats classified into to five groups (6 rats). The first group was kept as a negative control and fed on the basal diet only. Other four groups were administered sodium arsenite at a single dose of 5 $m g / k g / d a y$ to induce toxicity injury. One of these groups left as positive control (group 2). The third group was treated with $100 \%$ wheat flour fortified cake. The fourth group was treated with $10 \%$ ashwagandha powder fortified cake. The fifth group was treated with $20 \%$ ashwagandha powder fortified cake. Laboratory analysis showed that fortification with ashwagandha inhibited the levels of liver injury biomarkers, also improved the kidney function enzymes. These results suggested that ashwagandha has a powerful antioxidant effect which can reduce organ injury through its ability by scavenge the free radical.

Key words: Ashwagandha, Sodium Arsenite, Anti-amnesiac, Hepatotoxicity. 
INTRODUCTION

Ashwagandha" Withania somnifera" also known as winter cherry is one of the most powerful traditional Indian herbs used in Ayurvedic medicine (Chatterjee and Pakrashi, 1995). Ashwagandha is belonging to family Solanaceae with oval leaves and yellow flowers. It bears red fruit which is native to the dry regions of India, and the Middle East (Gupta, et al., 2011). The chemical composition of ashwagandha roots contain high level of protein $(10.72 \%)$, ash $(5.41 \%)$, crude fiber $(14.58 \%)$ and total carbohydrates (65.80\%) (Pingali, et al., 2014). Many pharmacological studies and investigations have been conducted to study the effects of ashwagandha for human health in an attempt to find its use as a medicinal agent( Mirjalili, et al., 2009) in Ayurveda medicine or alternative medicine, ashwagandha is used for improving thinking ability, arthritis, decreasing pain ,anxiety, chronic liver disease, asthma and as an adaptogen to increase energy to stand the daily stress (Ingrid Hehmeyer and Hanne Schönig Herbal Medicine in Yemen, 2012) .

Recently, ashwagandha shows an anti-amnesiac effect against streptozotocin in neurological degenerative disease which can be a promising alternative treatment for Alzheimer's disease as it improves the formation of memories and physical performance (Baitharu, et al., 2013).

Arsenic is a naturally occurring element and released into the environment through agriculture and industry that ubiquitously exists as trivalent $\left(\mathrm{As}^{3+}\right.$, arsenite) and pentavalent $\left(\mathrm{As}^{5+}\right.$, arsenate) forms, and arsenite has been considered to be more toxic when compared with arsenate (Domingo, 1995 and Baitharu, et al., 2013).

Sodium arsenite is an inorganic compound with the formula $\mathrm{NaAsO}_{2}$ which may be inhaled or absorbed through the skin (Grund, et al., 2005). According to clinical observations, the chronic arsenic exposure is a cause of 
various disorders such as diabetes mellitus, cardiovascular diseases, nephrotoxicity, and cancer of the skin, bladder and neurotoxicity. In addition, it has been suggested to affect the liver function and to induce hepatotoxicity. During arsenic metabolism, oxygen radicals can be produced frequently which lead to overproduction or accumulation of oxygen free radicals in cells causing damage of DNA, lipids and proteins (Gurr, et al., 2003). Acute sodium arsenite poisoning may lead to abdominal pain, diarrhea, poor appetite and nausea (Ratnaike, 2003). Accumulation of arsenite in vital tissues and organs due to chronic poisoning of sodium arsenite can lead to convulsions, decreased blood pressure, nervous system damage, headache, weakness, eventual paralysis and death (ICPEMC, 1990).

Food fortification is a modern strategy which refers to the addition of micronutrients to processed foods (World Health Organization and Food and Agriculture Organization of the United Nations, 2006). Reducing micronutrient malnutrition is considered as prime goal of food Fortification to provide adequate levels of the respective nutrients in the diet. In many situations, this strategy can lead to use this nutritional supplementation as medicine which is used in treating many disorders including cancers, also it can used to ensure approaching nutrient deficiencies among people (Gerrior, et al., 2004). The purpose of this study is to review and evaluate the influence of fortified cakes with ashwagnda on the levels of some physiological parameters as kidneys function, liver function and lipid profile of chronic renal failure in rats.

\section{MATERIALS \&METHODS}

\section{Materials}

Animals: Thirty male albino rats, Sprague Dawley strain, weighing $(120 \pm 10 \mathrm{~g})$ were purchased from the animal house of Agriculture Research Center, Giza, Egypt. The animals were housed in plastic cages, maintained on a natural 
Samah A. Elsemelawy and Rehab Ibrahim Tag Al Deen

light-dark cycle at room temperature of $26 \pm 2^{\circ} \mathrm{C}$ and fed standard diet according to (Reeves, et al., 1993).

\section{Chemical and plant products:}

-Sodium Arsenite ${ }^{\odot}$ : $(\mathrm{NaAsO} 2)$ was obtained from Sigma Chemical Co. (St Louis, Mo, USA). Minerals and vitamins constituent, sucrose, glucose and absolute ethanol were obtained from El-Gomhoriya Pharm. and Chem. Ind. Co. Cairo, Egypt.

-Casein (> 85\% protein) was obtained from Misr Scientific Company, Giza, Egypt. Cellulose and DL- methionine were purchased from Morgan Company, Cairo, Egypt.

- Corn oil was obtained from the local market. Corn starch was obtained from Starch and Glucose Company, Helwan, Egypt.

-Ashwagandha

(Withania somnifera) roots and were purchased as dried material from local market in Cairo. Egypt.

-American Wheat flour (72\%), sucrose, skim milk, whole egg, salt, baking powder, vanillin, margarine were purchased from local market in Cairo. Egypt.

\section{Methods:}

\section{Phytochemical composition:}

Analyzed phytochemical constituents of the roots of the major phytoconstituents were determined by using the methods of (Adesanya and Sofowora, 1983).

Preparation of Fortified cakes: Fortified cakes were prepared according to the common method of (Penfield and Campbell, 1990). Preparation of cake was carried out by using wheat flour (72\%), samples replaced separately with 10 and $20 \%$ ashwagandha powder.

\section{Experimental design:}

The experiment was performed in Animal House in the Food Technology Research Institute, Agriculture Research Center, Giza. After the acclimatization period, rats were divided randomly into two main groups, the first main group ( $\mathrm{n}=$ 6 rats) fed on the basal diet only 
as a negative control. While, the second main group $(\mathrm{n}=24$ rats) were sodium arsenite administration ( $\mathrm{Sa}, 5 \mathrm{mg} / \mathrm{kg} \mathrm{BW}$ per day) the selection of arsenic dose and procedure of administration were based on the prior study to (Chattopadhyay, et al., 2003). The second main group was given orally $10 \mathrm{ml}$ of water containing sodium arsenite at the dose of $5 \mathrm{mg}$ per $\mathrm{kg}$ body weight per day) which classified into positive control (+ve) group and three treated rat groups that treated with cake $100 \%$ wheat flour (10g/100 g Basel diet), fortified cake with $10 \%$ ashwagandha powder $(10 \mathrm{~g} / 100$ $\mathrm{g}$ Basel diet), fortified cake with $20 \%$ ashwagandha powder $(10 \mathrm{~g}$ /100 g Basel diet). Body weight (BW) was recorded weekly during the experimental period and feed intake was measured daily during the experimental periods. At the end of the experiment, biological evaluation of the tested diets was carried out by determining total feed intake, body weight gain (BWG) and food efficiency ratio (FER).
Blood sampling:

At the end of the experiment period (8 weeks), rats were sacrificed after overnight fasting under ether anesthesia. Blood samples were taken from hepatic portal vein and were left to clot by standing at room temperature for 15 minutes, and then centrifuged at $3000 \mathrm{rpm}$ for 20 minutes. Serum was carefully separated and transferred into clean quite fit plastic tubes and kept frozen at $20^{\circ} \mathrm{C}$ until the time of analysis.

\section{Biochemical analysis:}

Serum alanine and aspartate aminotransferases (ALT \& AST) were estimated according to (Reitman and Frankel, 1957) while alkaline phosphatase (ALP) was assayed by (Kind and King, 1954) and bilirubin levels were estimated according to Bartholomev and Delany, (1966). Serum creatinine, uric acid and urea were determined according to the methods described by (Bohmer, 1971; Fossati et al., 1980 and Patton and Crouch, 1977), respectively. Enzymatic colorimetric determination of 
triglycerides was carried out according to (Fossati and Prencipe, 1982). Total cholesterol was determined by colorimetric method according to (Allian, et al., 1974). Determination of HDL-c (high density lipoprotein) was carried out according to the method of (Fnedewaid, 1972). The determination of VLDL-c (very low density lipoproteins) and LDL-c (low density lipoproteins) were carried out according to the method of (Lee and Nieman, 1996) by calculation as follows:

* VLDL-c $(\mathrm{mg} / \mathrm{dl}) \quad=$ Triglycerides $/ 5$

* LDL-c $(\mathrm{mg} / \mathrm{dl})=$ Total cholesterol -HDL-c-VLDL-c Acetyl cholinesterase (AchE) activity was determined according to (Knedel and Boottger, 1967). Superoxide dismutase (SOD) activity, total antioxidants capacity (TAC), and malondialdehyde (MDA) were determined according to (Nishikimi, et al., 1972; Cao, et al., 1993 and Oh-kawa, et al., 1979), respectively.
Statistical analysis:

The obtained data were statistically analyzed using computerized SPSS (Statistic Program Sigmastat, Statistical Soft-Ware, SAS Institute, Cary, NC). Effects of different treatments were analyzed by one way ANOVA (Analysis of variance) test using Duncan's multiple range test and $p<0.05$ was used to indicate significance between different groups (Snedecor and Cochran, 1967).

\section{RESULTS \& DISCUSSION}

Fig (1) shows the phytonutrient constituents of ashwagandha roots, the highest phenolic compound concentration in ashwagandha roots was chlorogenic acid. ashwagandha roots also contain pyrocatechol, caffeic acid, ferutic acid, protocatechuic acid, vanillic acid and pyrogallol.

Table (1) discusses the effect of sodium arsenite and the other treated groups on body weight gain and feed intake. The results indicated that the control group (+ve) Showed a significant decrease in body 
weight gain and feed intake compared to Normal control group while the other treated groups showed significant increase in these parameter compared with control group (+ve). There wasn't a significant difference between the treating with ashwagandha powder and wheat flour on body weight gain and feed intake. Our results were matchd with (Mane, et al., 2012), who reported that Inclusion of aswaganda powder in broiler food was beneficial in improving the body weight and feed intake ratio.

The effect

of ashwagandha powder fortified cake on liver function enzymes in rats received $\mathrm{NaAsO} 2$ are presented in Table 2. The elevation of liver function enzymes was due to the injury caused by $\mathrm{NaAsO} 2$, as the positive group (+ve) showed a significant increase in total bilirubin, AST and ALT in comparing to normal control group (-ve). On the other hand, the treated groups with different concentrations of ashwagandha powder improved the results as those levels were found to be significantly lower in comparing to positive group (+ve). specifically, the cake fortified with ashwagandha powder at different concentrations was better than $100 \%$ wheat flour cake in lowering the elevation of hepatic enzymes caused by $\mathrm{NaAsO} 2$.

\section{Similarly Udayakumar,} (2009) clarified that both ashwaganda root and leaf have a great role in decreasing the circulating liver enzymes In diabetic animals induced by alloxan at $200 \mathrm{mg} / \mathrm{kg}$. Moreover, (Hosny and Farouk, 2012) aimed to investigate the protective effect of ashwaganda extract against irradiation of gamma-induced oxidative stress in hepatic cells. His results were closely matched to our study as he suggested that ashwaganda extract abrogated the increases in liver enzymes so it could be used as a preventive drug which protects the hepatic cells in radiotherapy.

Thus, it may be due to the hepatoprotective action of Withanolide A which is exist in ashwaganda by alleviating oxido-nitrosative stress and 
inflammatory via inhibition of interleukin-1(IL-1 $\beta$ ),

cyclooxygenase activity (COX-

2), tumor necrosis factor-alpha $(\mathrm{TNF}-\alpha)$ and total nitric oxide (INOS). Hence, ashwaganda exerts a hepatoprotective effect through several mechanisms which could be attributed to the ability to remove the urea related compounds and antioxidant properties (Dhuley, 2000).

In Table (3), results showed that kidney function tests were elevated by $\mathrm{NaAsO} 2$ as it shown in positive group (+ve). The changes in the kidney function tests were due to $\mathrm{NaAsO} 2$ induced kidney injury, as there was significant increase in urea, uric acid and creatinine compared to normal group (-ve). Meanwhile, the other treated groups reversed those results as there was a significant decrease in the levels of creatinine, urea and uric acid except the $100 \%$ wheat flour group, as there is a non significant difference in uric acid level compared to positive group. Fortified cake with $20 \%$ ashwaganda powder showed the best results as shown in table (3). Recently (Jeyanthi and Subramanian, 2009) investigated the nephroprotective role of withania somnifera on gentamicin induced nephrotoxicity in mice. These studies showed that $500 \mathrm{mg} / \mathrm{kg}$ of root extract of ashwagandha given to albino rats for two weeks prior to gentamicin induced renal toxicity was able to attenuate the increase in urinary protein and serum creatinine.

Furthermore,

ashwagandha contain many of withanolides and alkaloids. (Harikrishnan, et al., 2008) withaferin A, 1-oxo-5b, 6bepoxy-witha-2-ene-27-etnoxyolide, etc, 32, 33 are the main active compounds in ashwagandha (Jayaprakasam, 2003). They have the ability to increase the glomerular filteration rate (GFR) which decrease the serum urea and creatinine levels.

$\mathrm{NaAsO} 2$ induced toxicity (positive group) caused a significant rise in total cholesterol, triglycerides, 
VLDL-C and LDL-C while, there was significant decrease in HDL-C in comparing to normal group (-ve) as it shown in table (4). This is due to accumulation of sodium arsenite in liver and kidneys after excessive doses (Engel, et al., 1994).

On the other hand, the other treated groups showed significant decrease in serum total cholesterol, triglycerides, VLDL-C and LDL-C while increase in HDL-C compared to positive group (+ve). The fortification with $10 \%$ and $20 \%$ of ashwagandha demolishes the negative impact of $\mathrm{NaAsO} 2$ on lipid profile more than $100 \%$ wheat flour group.

Our results were matched with (Visavadiya and Narasimhacharya, 2011) who found that the supplementation of ashwagandha in albino rats with normal cholesterol level for four weeks was seems to decrease the total cholesterol (10.5-16.6\%). $\mathrm{He}$ also investigated the effect of ashwagandha in diet-induced hypercholesterolemic, founding that there was significant decreasing in LDL-C (49.2-
$62.7 \%$ ) with a significant increase in HDL-C (15.1$17.7 \%)$. In other study, there was a reduction in LDL level in otherwise healthy persons who did not have elevated LDL cholesterol at baseline when the subjects given $750-1,250 \mathrm{mg}$ of the water extract (Raut, 2012). (Bhattacharya, et al., 1997) have suggested that ashwagandha exerts the Hypolipidaemic effect due to the antioxidant effect which may be responsible for its pharmacological properties.

Table (5) represent the results of the Effect of ashwagandha on antioxidant parameters in rats received $\mathrm{NaAsO} 2 . \quad \mathrm{NaAsO} 2$ induced toxicity caused significant decrease in serum antioxidant enzyme activity; superoxide dismutase SOD and total antioxidants level while increase in malondialdehyde (MDA) activity compared to normal group (-ve). On the other hand, all other treated groups significantly attenuated the decreased levels of MDA and elevated the serum antioxidant enzyme levels in comparing to 
positive group (+ve). This result was agreed with (Visavadiya and Narasimhacharya, 2011) who noted that lipid peroxidation (MDA) is reduced $12.4-18.2 \%$ when rats fed 0.75 $1.5 \%$ of the diet as ashwagandha root. These antiperoxidative action observed in are most likely due to free radical scavenging activity of ashwagandha specially at concentration $20 \%$. The potent antioxidant power in ashwagandha is may be due to the presence of several compounds like, flavanoids, alkaloids withanolides and withaferin-A. The reduction in the increased levels of lipid peroxidation because the ashwagandha is known as a good source of flavanoids and polyphenolic compounds which they are consider as potent free radical scavengers, including hydroxyl and superoxide anions ( Jovanovic and Simic, 2000). Also ashwagandha root powder proved to have another compounds such as sitoindosides VII-X which have also an antioxidant activity (Bhattacharya, et al., 1997).

\section{CONCLUSION}

From the above study results, it may be concluded that fortification with ashwagandha (Withania somnifera) root powder at different concentration possess antioxidant and antihyperlipidaemic activities in $\mathrm{NaAsO} 2$-induced toxicity in rats and may have some role in decreasing serum urea and creatinine levels. Ashwagandha root powder appears to prevent the oxidative damage to kidney and liver tissue.

\section{REFERENCES}

Adesanya, S.A and Sofowora, E.A. (1983):

Biological

standardization of Zanthoxylum roots for antisickling activity. Plant Med. 48: 27-33.

Allian, C., Poon, L., Chan, C. and Richmond, W. (1974):

Enzymatic determination of total serum cholesterol. Clin. Chem.; 20: 470. 
Baitharu, I., Jain, V., Deep, S.N., Hota, K.B., Hota, S.K., Prasad, D., and Ilavazhagan, G. (2013):

Withania somnifera root extract ameliorates hypobaric hypoxia induced memory impairment in rats. $\mathbf{J}$ Ethnopharmacol. Jan 30;145(2):431-41.

Bartholomev, R.J. and Delany, A. (1966):

Proc Aust. Assoc. Biochemists. 1, 214.

Bayne, C.J. Gerwick, L. Fujiki, K. Nakao, M. and Yano, T. (2006):

Immune-relevant

(including acute phase) genes identified in the livers of rainbow trout, Oncorhynchus mykiss, by means of suppression subtractive hybridization, Dev. Comp. Immunol. 25 205-217.
Bhattacharya, S.K., Satyan, K.S., and Chakrabarti, A. (1997):

Effect of Trasina, an Ayurvedic herbal formulation on pancreatic islet superoxide dismutase activity in hyperglycaemic rats. Indian J Exp Biol. 35(3):297-9.

Bhattacharya, S.K., Satyan, K.S., and Ghosal S. (1997):

Antioxidant activity of glycowithanolides from Withania somnifera. Indian $\mathrm{J}$. Exp.Biol.(1997) 3523 6-239.

Bohmer, H. (1971):

Micro-determination of creatinine. Clin. Chem. Acta.; 32:81-85.

Cao, G.; Alessio, H. and Cutler, R. (1993):

Oxygen radical absorbance capacity assay for antioxidants. Free Radic Biol Med.; 14:303-311. 
Chatterjee, A., and Pakrashi, S.C. (1995):

The Treatise on Indian Medicinal Plants 4:208-212.

Chattopadhyay, S., Ghosh, S., Chaki, S., Ghosh, D., and Debnath J.(2003):

Effect of dietary coadministration of sodium selenite on arsenite- induced ovarian and uterine disorders in mature albino rats. Toxicol Sci. 75: 412-422.

Dhuley, J. N. (2000):

Adaptogenic and cardioprotective action of ashwagandha in rats and frogs. $\mathbf{J}$. Ethnopharmacol., 70, 57.

Domingo, J. L. (1995):

Prevention by chelating agents of metal-induced developmental toxicity. Reprod Toxicol. 1995 Mar-Apr; 9(2):105-13. .
Engel, R.R., Hopenhayn-Rich C., Receveur, O., and Smith, A.H. (1994):

Vascular effects of chronic arsenic exposure: a review. Epidemiol Rev. 16: 184-209

Fnedewaid, W.T. (1972):

Determination of HDL-c . Clin. Chem.; 8:499.

\section{Fossati, P. and Prencipe,}

L.(1982):

Determination

of triglycerides, Bicon Diagnostics, made in Germany. Clinical Chemistry; 28: 20772078. .

Fossati, P.; Prencipe, L. and Berti, G. (1980):

Use of 3.5 dichloro-zhydroxybenzenesulfoni c acid / 4 aminophenazone chromogenic systems in direct enzymic assay of uric acid in serum and 
urine. Clin. Chem.; Gurr, J.R., Yih, L.H.,

26:227- 231.

Gerrior Shirley., Bente, Lisa. and Hiza Hazel. (2004):

Nutrient Content of the

U.S. Food Supply.

Home Economics

Research Report No.

56, U.S. Department of

Agriculture, Center for

Nutrition Policy and

Promotion: 45.

Grund, S. C., Hanusch, K., and Wolf, H. U. (2005):

Arsenic and Arsenic

Compounds. Ullmann's

Encyclopedia of

Industrial Chemistry,

Weinheim: Wiley-

$\mathrm{VCH}$, 10.1002. 03113.

Gupta, A., Mittal, A., Jha, K. K. and Kumar, A. (2011):

Nature's treasurer:

plants acting on colon

cancer" Journal of

Stress Physiology \&

Biochemistry 7 (4):

217-231.
Samikkannu, T., Bau, D.T., Lin, S.Y., and Jan, K.Y. (2003):

Nitric oxide production by arsenite. Mutat Res. 10; 533(1-2):173-82.

Harikrishnan, B., Subramanian, P., and Subash, S. (2008):

Effect of Withania somnifera root powder on the levels of circulatory lipid peroxidation and liver marker enzymes in chronic

Hyperammonemia.

E.Journal of Chemistry. 5(4): 872877.)

Hosny Mansour H., and Farouk Hafez, H. (2012):

Protective effect of Withania somnifera against radiationinduced hepatotoxicity in rats . Ecotoxicol Environ Saf. 80:14-9.

ICPEMC (1990): 


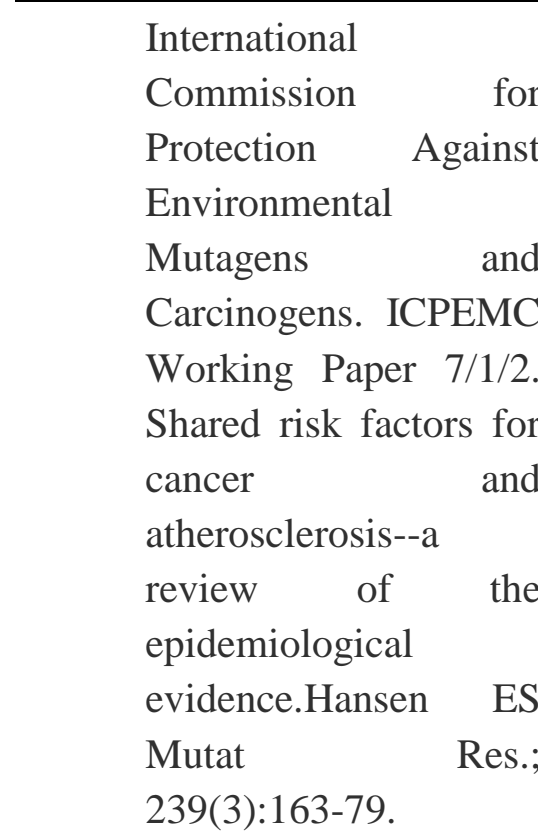

Ingrid Hehmeyer and Hanne Schönig, Herbal Medicine in Yemen (2012):

Traditional Knowledge and Practice, and Their Value for Today's World, Series: Islamic History and Civilization (vol. 96), Brill: Leiden, P. 200 ISBN 978-90-0422150-5.

Jayaprakasam, B., Zhang, Y., Seeram, N. P. and Nair, M. G.(2003):

Plant products as functional foods and botanical medicines to improve human, animal and plant health. Life Sci., 74, 125.

Jeyanthi, T., and Subramanian, P. (2009):

Nephroprotective effect of withania somnifera: a dosedependent study. Ren Fail. 31(9):814-21.

Jovanovic, S.V. and Simic, M.G. (2000):

Antioxidants in nutrition. Ann. NY

Acad. Sci. 899 326334.

Kind, P.R. and King, E.J. (1954):

Estimation of alkaline phosphatase activity by determination of hydrolyzed phenol with aminoantipyrene. J. Clin.Path.7: 322.

Knedel, M. and Boottger, R. (1967):

A kinetic method for determination of the 
activity of pseudo

cholinesterase. Klin.

Wochenschr; 45: 325327.

Lee, R. and Nieman, D. (1996):

Nutritional assessment. 2 nd Ed., Mosby, Missoun, USA.

Mane, A.G. Kulkarni, A.N. Korake, R.L. and Bhutkar, S.S. (2012):

Effect of supplementation of Ashwagandha

(Withania somnifera) and Shatavari (Asparagus racemosus) on growth performance of broilers. Research Journal of Animal Husbandry and Dairy Science. Volume 3 . Issue 2. December, 9496.

Mirjalili, M. H., Moyano, E., Bonfill, M., Cusido, R. M., and Palazón, J. (2009):

Steroidal Lactones from Withania somnifera, an Ancient
Plant for Novel Medicine. Molecules 1 4 (7): 2373-2393.

Nishikimi, M.; Rao, N. and Yogi, K. (1972):

Colorimetric

determination of superoxide dismutase. Biochem. Biophys. Res. Common.; 46: 849-854.

Oh-kawa, H., Ohishi, N. and Yagi, K. (1979):

Assay for lipid peroxides in animal tissues by thiobarbituric acid reaction. Anal Biochem.; 95: 351358.

Patton, C. and Crouch, S. (1977):

$\begin{array}{lr}\text { Determination } & \text { of } \\ \text { serum } & \text { urea } \\ \text { enzymatically. } & \text { J.of }\end{array}$ Ana. Chem. 49 : 464 469.

Penfield, M.P. and A.M. Campbell, (1990): 
Evaluating food by objective methods. In Experimental Food Science, 3rd ed. pp. 2345. Academic Press, Inc. San Diego, CA.

Pingali, U., Pilli, R., and Fatima, N. (2014):

Effect of Ashwagandha on Tests of Cognitive and Psychomotor Performance.

Pharmacognosy Res. 6(1):12-18.

Ratnaike, R.N. (2003):

Acute and chronic arsenic toxicity. Postgrad Med J. 2003 Jul; 79(933):391-6.

Raut, A.A. (2012): Exploratory study to evaluate tolerability, safety, and activity of Ashwagandha (Withania somnifera) in healthy volunteers . J

Ayurveda Integr Med. BMJ Case Reports. 10.1136 -2012-007052.
Reeves, P., Nielson, F. and Fahmy, G. (1993):

Reports of the American Institute of Nutrition, Adhoc Wiling Committee on reformulation of the AIN 93. Rodent Diet. J. Nutri.; 123: 19391951.

Reitman, S. and Frankel, S. (1957):

Determination of serum alanine and aspartate aminotransferases (ALT \& AST). Clin .Path. Am. J. 28: 57-63.

Snedecor, G.W. and Cochran, W.G. (1967):

Statistical

Methods; $7^{\text {th }}$ Ed., The

Lowa State University Press., Ames, Lowa, U.S.A.

Udayakumar, R. (2009):

Hypoglycaemic and hypolipidaemic effects of Withania somnifera root and leaf extracts on alloxan-induced diabetic rats. The 
Effect of Feeding Cake Fortified with Different Concentrations of Ashwagandha Root Against Sodium Arsenite Toxicity in Male Rats

Samah A. Elsemelawy and Rehab Ibrahim Tag Al Deen

National Institute of

Technology. 1313-

132011.
Visavadiya, N.P., and Narasimhacharya, (2011):

Hypocholesteremic and antioxidant effects of Withania somnifera (Dunal) in rats. Oxid Med Cell Longev. 160408.

\section{World Health Organization} and Food and Agriculture Organization of the United Nations, (2006):

Guidelines on food fortification with micronutrients, cited on Oct 30 . 


\section{Fig 1: Phytonutrient constituent of ashwagandha roots}

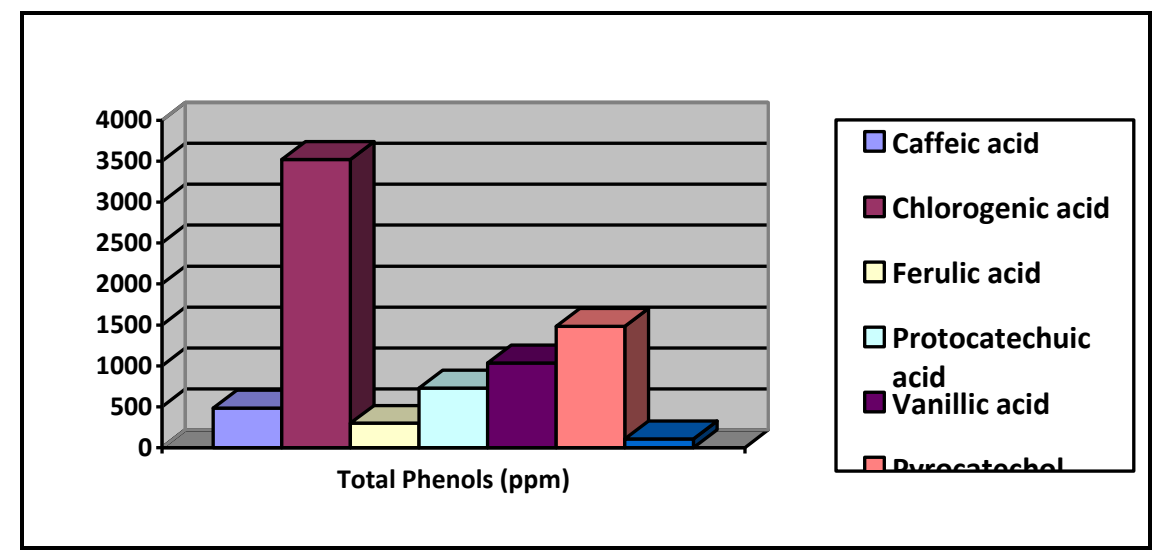

Table (1): Effect of fortified with ashwagandha on feed intake, body weight gain $\%$ in rats received $\mathrm{NaAsO} 2$

\begin{tabular}{|c|c|c|c|}
\hline \multicolumn{2}{|c|}{ Parameters } & $\begin{array}{c}\text { Feed intake } \\
\text { g/day }\end{array}$ & $\begin{array}{c}\text { Body weight gain } \\
\%\end{array}$ \\
\hline \multicolumn{2}{|c|}{ Normal control group } & $\begin{array}{r}19.43 \\
\pm 2.31^{\mathrm{a}}\end{array}$ & $\begin{array}{c}94.10 \\
\pm 9.80^{\mathrm{a}}\end{array}$ \\
\hline \multicolumn{2}{|c|}{ Fontrol group (+ve) } & $\begin{array}{r}12.86 \\
\pm 2.75^{\mathrm{c}}\end{array}$ & $\begin{array}{l}51.15 \\
\pm 7.62^{c}\end{array}$ \\
\hline \multirow{3}{*}{ 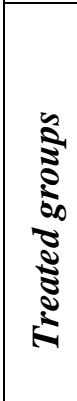 } & $\begin{array}{c}\text { Wheat flour } \\
100 \%\end{array}$ & $\begin{array}{r}16.85 \\
\pm 2.24^{\mathrm{b}}\end{array}$ & $\begin{array}{c}77.46 \\
\pm 8.07^{\mathrm{b}}\end{array}$ \\
\hline & $\begin{array}{c}\text { Ashwagandha } \\
\text { powder } \\
10 \%\end{array}$ & $\begin{array}{c}16.99 \\
\pm 2.19^{\mathrm{b}}\end{array}$ & $\begin{array}{c}71.37 \\
\pm 10.8^{b}\end{array}$ \\
\hline & $\begin{array}{c}\text { Ashwagandha } \\
\text { powder } \\
20 \%\end{array}$ & $\begin{array}{c}17.72 \\
\pm 2.37^{\mathrm{b}}\end{array}$ & $\begin{array}{c}72.12 \\
\pm 9.19^{\mathrm{b}}\end{array}$ \\
\hline
\end{tabular}

Values are expressed as mean \pm SD. Significance at $\mathrm{p}<0.05$.

Values which don't share the same letter in each column are significantly different. 
Table (2): Effect of fortified with ashwagandha on liver functions in rats received $\mathrm{NaAsO2}$

\begin{tabular}{|c|c|c|c|c|}
\hline \multicolumn{2}{|c|}{$\mathrm{Croups}_{\text {Grometers }}$ Parameter } & $\begin{array}{c}\text { AST } \\
(\mu / \mathrm{ml})\end{array}$ & $\begin{array}{c}\text { ALT } \\
(\mu / \mathrm{ml})\end{array}$ & $\begin{array}{c}\text { Total bilirubin } \\
\mathrm{mg} / \mathrm{dl}\end{array}$ \\
\hline \multicolumn{2}{|c|}{ Normal control group } & $\begin{array}{r}43.63 \\
\pm 8.50 \mathrm{~b}\end{array}$ & $\begin{array}{r}39.07 \\
\pm 3.43 \mathrm{c}\end{array}$ & $\begin{array}{c}0.49 \\
\pm 0.03 \mathrm{~d}\end{array}$ \\
\hline \multicolumn{2}{|c|}{ control group (+ve) } & $\begin{array}{r}79.67 \\
\pm 9.03 \mathrm{a}\end{array}$ & $\begin{array}{c}74.67 \\
\pm 6.84 \mathrm{a}\end{array}$ & $\begin{array}{r}1.06 \\
\pm 0.08 \mathrm{a}\end{array}$ \\
\hline \multirow{3}{*}{ 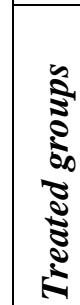 } & $\begin{array}{c}\text { Wheat flour } \\
100 \%\end{array}$ & $\begin{array}{c}64.67 \\
\pm 8.15 \mathrm{a}\end{array}$ & $\begin{array}{c}54.67 \\
\pm 5.51 \mathrm{~b}\end{array}$ & $\begin{array}{c}0.75 \\
\pm 0.24 \mathrm{~b}\end{array}$ \\
\hline & $\begin{array}{l}\text { Ashwagandha } \\
\text { powder } 10 \%\end{array}$ & $\begin{array}{c}46.23 \\
\pm 6.27 \mathrm{~b}\end{array}$ & $\begin{array}{r}47.33 \\
\pm 8.92 \mathrm{bc}\end{array}$ & $\begin{array}{r}0.57 \\
\pm 0.39 \mathrm{c}\end{array}$ \\
\hline & $\begin{array}{l}\text { Ashwagandha } \\
\text { powder } 20 \%\end{array}$ & $\begin{array}{c}43.01 \\
\pm 7.48 \mathrm{~b}\end{array}$ & $\begin{array}{r}39.67 \\
\pm 8.08 \mathrm{bc}\end{array}$ & $\begin{array}{c}0.48 \\
\pm 0.13 \mathrm{~d}\end{array}$ \\
\hline
\end{tabular}

Values are expressed as mean \pm SD. Significance at $\mathrm{p}<0.05$.

Values which don't share the same letter in each column are significantly different. AST: Aspartate aminotransferase.

ALT: Alanine aminotransferase.

Table (3): Effect of fortified with ashwagandha on kidney functions in rats received $\mathrm{NaAsO2}$

\begin{tabular}{|c|c|c|c|c|}
\hline \multicolumn{2}{|c|}{$\mathrm{Cr}_{\text {Groups }}$ Parameters } & $\begin{array}{c}\text { Uric acid } \\
\mathrm{mg} / \mathrm{dl}\end{array}$ & $\begin{array}{c}\text { Creatinine } \\
\mathrm{mg} / \mathrm{dl}\end{array}$ & $\begin{array}{l}\text { Urea } \\
\mathrm{mg} / \mathrm{dl}\end{array}$ \\
\hline \multicolumn{2}{|c|}{ Normal control group } & $\begin{array}{c}2.73 \\
\pm 0.78 \mathrm{~b}\end{array}$ & $\begin{array}{c}1.02 \\
\pm 0.07 \mathrm{~b}\end{array}$ & $\begin{aligned} & 40.67 \\
\pm & 3.06 \mathrm{~d}\end{aligned}$ \\
\hline \multicolumn{2}{|c|}{ Control group (+ve) } & $\begin{aligned} & 5.18 \\
\pm & 0.52 \mathrm{a}\end{aligned}$ & $\begin{array}{r}1.97 \\
\pm 0.31 \mathrm{a}\end{array}$ & $\begin{array}{l}64.03 \\
\pm 2.65 \mathrm{a}\end{array}$ \\
\hline \multirow{3}{*}{ 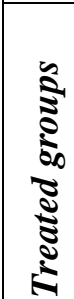 } & $\begin{array}{c}\text { Wheat flour } \\
100 \%\end{array}$ & $\begin{array}{r}4.80 \\
\pm 0.57 \mathrm{a}\end{array}$ & $\begin{array}{c}1.47 \\
\pm 0.15 \mathrm{~b}\end{array}$ & $\begin{array}{r}54.0 \\
\pm 7.64 \mathrm{~b}\end{array}$ \\
\hline & $\begin{array}{l}\text { Ashwagandha } \\
\text { powder } 10 \%\end{array}$ & $\begin{array}{c}2.91 \\
\pm 0.72 \mathrm{~b}\end{array}$ & $\begin{array}{c}1.51 \\
\pm 0.22 \mathrm{~b}\end{array}$ & $\begin{array}{c}50.67 \\
\pm 6.35 \mathrm{~b}\end{array}$ \\
\hline & $\begin{array}{c}\text { Ashwagandha powder } \\
20 \%\end{array}$ & $\begin{array}{c}2.82 \\
\pm 0.93 \mathrm{~b}\end{array}$ & $\begin{array}{c}1.19 \\
\pm 0.06 \mathrm{~b}\end{array}$ & $\begin{array}{r}42.01 \\
\pm 3.21 \mathrm{c}\end{array}$ \\
\hline
\end{tabular}

Values are expressed as mean \pm SD. Significance at $\mathrm{p}<0.05$.

Values which don't share the same letter in each column are significantly different. 
Table (4): Effect of fortified with ashwagandha on lipid profile in rats received $\mathrm{NaAsO} 2$

\begin{tabular}{|c|c|c|c|c|c|}
\hline Groups & $\begin{array}{c}\mathrm{TC} \\
\mathrm{mg} / \mathrm{dl}\end{array}$ & $\begin{array}{c}\text { TG } \\
\mathrm{mg} / \mathrm{dl}\end{array}$ & $\begin{array}{c}\text { VLDL-c } \\
\text { mg/dl }\end{array}$ & $\begin{array}{c}\text { LDL-c } \\
\mathrm{mg} / \mathrm{dl}\end{array}$ & $\begin{array}{c}\text { HDL-c } \\
\text { mg/dl }\end{array}$ \\
\hline Normal control group & $\begin{array}{l}82.27 \\
\pm 4.16 \mathrm{~d}\end{array}$ & $\begin{aligned} & 68.13 \\
\pm & 2.97 \mathrm{~d}\end{aligned}$ & $\begin{array}{l}13.62 \\
\pm 0.59 \mathrm{~d}\end{array}$ & $\begin{array}{c}31.16 \\
\pm 5.99 \mathrm{e}\end{array}$ & $\begin{array}{r}37.50 \\
\pm 2.29 \mathrm{a}\end{array}$ \\
\hline Control group (+ve) & $\begin{array}{l}101.57 \\
\pm 4.71 \mathrm{a}\end{array}$ & $\begin{array}{r}114.33 \\
\pm 10.66 \mathrm{a}\end{array}$ & $\begin{array}{r}20.78 \\
\pm 2.13 \mathrm{a}\end{array}$ & $\begin{array}{r}54.56 \\
\pm 3.55 \mathrm{a}\end{array}$ & $\begin{array}{r}26.23 \\
\pm 1.37 \mathrm{c}\end{array}$ \\
\hline $\begin{array}{c}\text { Wheat flour } \\
100 \%\end{array}$ & $\begin{array}{c}96.67 \\
\pm 7.26 \mathrm{~b}\end{array}$ & $\begin{array}{r}89.60 \\
\pm 3.14 \mathrm{~b}\end{array}$ & $\begin{array}{c}17.94 \\
\pm 0.63 \mathrm{~b}\end{array}$ & $\begin{array}{r}46.56 \\
\pm 5.76 b\end{array}$ & $\begin{array}{c}32.17 \\
\pm 1.76 \mathrm{~b}\end{array}$ \\
\hline $\begin{array}{cc} & \text { Ashwagandha powder } \\
0 & 10 \%\end{array}$ & $\begin{array}{r}89.80 \\
\pm 2.44 \mathrm{c}\end{array}$ & $\begin{array}{r}79.47 \\
+5.22 \mathrm{bc}\end{array}$ & $\begin{array}{r}15.89 \\
\pm 1.04 \mathrm{bc}\end{array}$ & $\begin{array}{r}39.77 \\
\pm 1.34 \mathrm{c}\end{array}$ & $\begin{array}{c}34.53 \\
\pm 3.02 \mathrm{~b}\end{array}$ \\
\hline $\begin{array}{c}\text { Ashwagandha powder } \\
20 \%\end{array}$ & $\begin{array}{c}84.27 \\
\pm 2.89 \mathrm{c}\end{array}$ & $\begin{aligned} & 74.27 \\
\pm & 1.42 \mathrm{~cd}\end{aligned}$ & $\begin{array}{c}14.98 \\
\pm 0.28 \mathrm{~cd}\end{array}$ & $\begin{array}{c}32.91 \\
\pm 3.66 \mathrm{~d}\end{array}$ & $\begin{array}{r}36.70 \\
\pm 2.07 \mathrm{a}\end{array}$ \\
\hline
\end{tabular}

Values are expressed as mean \pm SD. Significance at $\mathrm{p}<0.05$.

Values which don't share the same letter in each column are significantly different.

TG: Triglyceride TC: total Cholesterol

VLDLc: Very low density lipoprotein cholesterol

LDLc: Low density lipoprotein cholesterol HDLc: High density lipoprotein cholesterol 
Table (5): Effect of fortified with ashwagandha on antioxidant parameters in rats received $\mathrm{NaAsO} 2$

\begin{tabular}{|c|c|c|c|c|}
\hline \multicolumn{2}{|c|}{ Groups $\quad$ Parameters } & $\begin{array}{l}\mathrm{SOD} \\
\mathrm{U} / \mathrm{mL}\end{array}$ & $\begin{array}{c}\text { Total antioxidants } \\
\mathrm{mmol} / \mathrm{L}\end{array}$ & $\begin{array}{r}\mathrm{MDA} \\
\mathrm{mmol} / \mathrm{L}\end{array}$ \\
\hline \multicolumn{2}{|c|}{ Normal control group } & $\begin{array}{r}198.23 \\
\pm 12.74 \mathrm{a}\end{array}$ & $\begin{array}{r}3.12 \\
\pm 0.75 \mathrm{a}\end{array}$ & $\begin{array}{r}4.47 \\
\pm 0.76 \mathrm{c}\end{array}$ \\
\hline \multicolumn{2}{|c|}{ Control group $(+\mathrm{ve})$} & $\begin{array}{r}114.33 \\
\pm 12.01 \mathrm{c}\end{array}$ & $\begin{array}{c}1.17 \\
\pm 0.55 \mathrm{~b}\end{array}$ & $\begin{array}{r}11.05 \\
\pm 1.16 \mathrm{a}\end{array}$ \\
\hline \multirow{3}{*}{ 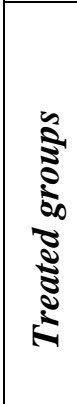 } & $\begin{array}{c}\text { Wheat flour } \\
100 \%\end{array}$ & $\begin{array}{r}147.12 \\
\pm 13.01 \mathrm{bc}\end{array}$ & $\begin{array}{r}1.23 \\
\pm 0.65 \mathrm{~b}\end{array}$ & $\begin{array}{c}8.2 \\
\pm 0.86 \mathrm{~b}\end{array}$ \\
\hline & $\begin{array}{c}\text { Ashwagandha } \\
\text { powder } \\
10 \%\end{array}$ & $\begin{array}{r}163.33 \\
\pm 14.81 \mathrm{~b}\end{array}$ & $\begin{array}{c}1.99 \\
\pm 0.80 \mathrm{ab}\end{array}$ & $\begin{array}{r}5.11 \\
\pm 0.62 \mathrm{c}\end{array}$ \\
\hline & $\begin{array}{c}\text { Ashwagandha } \\
\text { powder } \\
20 \%\end{array}$ & $\begin{array}{r}173.33 \\
\pm 14.15 \mathrm{a}\end{array}$ & $\begin{array}{r}2.73 \\
\pm 0.68 \mathrm{a}\end{array}$ & $\begin{array}{r}4.76 \\
\pm 0.43 \mathrm{c}\end{array}$ \\
\hline
\end{tabular}

Values are expressed as mean \pm SD. Significance at $\mathrm{p}<0.05$.

Values which don't share the same letter in each column are significantly different.

SOD: Superoxide dismutase. MDA: Malondialdehyde. 


\title{
تأثير التغذية بالكيك المدعم بواسطة تركيزات مختلفة

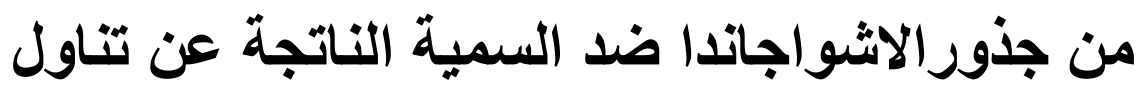 زرنيخ الصوديوم في ذكور الجرذان
}

\author{
سماح عبد الله السملاوي،' رحاب ابراهيم تاج الدين'

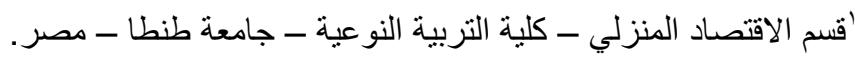

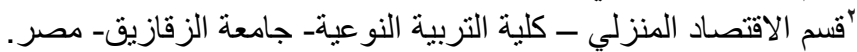

$$
\text { الملخص العربي }
$$

في الطب الهندي القديم، كانت النباتات العشبية مثل نباتالاشواجانداتعتبر من النباتات القوية

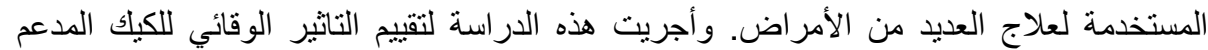

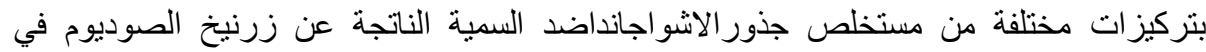

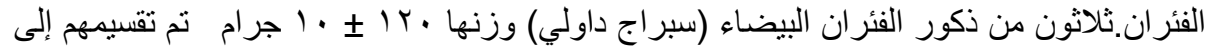

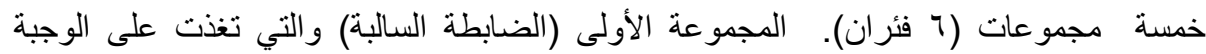

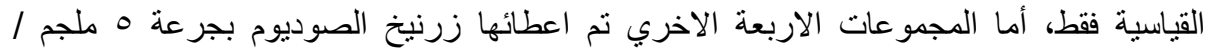

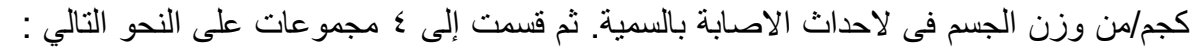

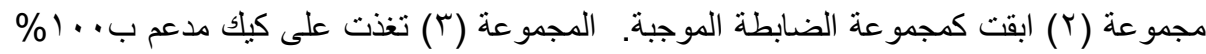

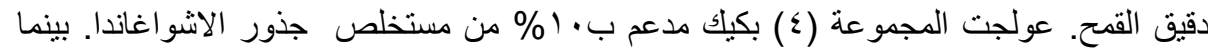

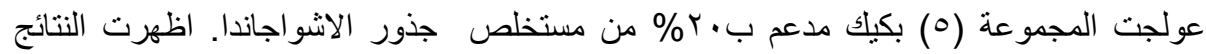

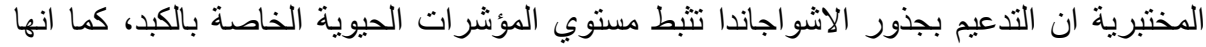

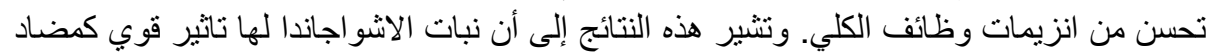
للاكسدة و التي تقلل من إصابة الاعضاء الحيوية عن طريق مسح الثقوق الحرة. 